JumalEkonomi Pembangunan Vol. 3, No. 2 (2017) 66-79

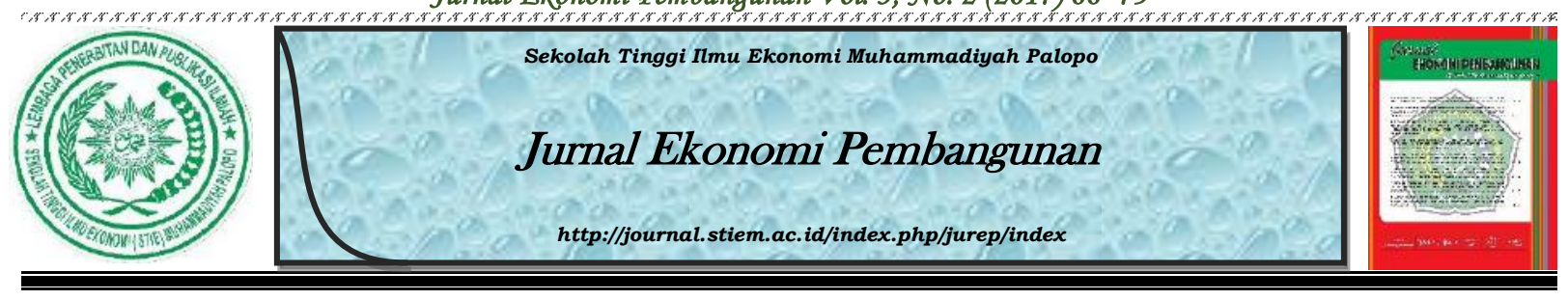

\title{
Penerapan Sistem dan Prosedur Penerimaan \\ Kas pada Rumah Sakit Umum Daerah (RSUD) Andi Makkasau Kota Parepare
}

\author{
Yasri Tarawiru ${ }^{1}$, Abd. Azis ${ }^{2}$ \\ 1,2 Universitas Muhammadiyah Parepare
}

\section{INFO NASKAH

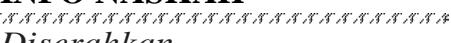 \\ Diserahkan \\ 9 September 2017 \\ Diterima \\ 16 Oktober 2017 \\ Diterima dalam revisi \\ 10 Desember 2017 \\ Diterima dan disetujui \\ 12 Desember 2017}

\section{Kata Kunci:}

Sistem

Prosedur

Penerimaan kas

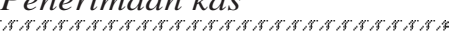

\begin{abstract}
ABSTRAK
Penelitian ini bertujuan untuk mengetahui penerapan sistem dan prosedur penerimaan kas pada Rumah Sakit Umum Daerah (RSUD) Andi Makkasau dan kesesuaiannya dengan Perda Kota Parepare Nomor 2 (dua) tahun 2017. Variabel yang diteliti yaitu sistem, prosedur dan penerimaan kas. Penelitian ini menggunakan pendekatan kualitatif untuk mengetahui bagaimana sistem dan prosedur penerimaan kas pada RSUD Andi Makkasau Kota Parepare. Hasil dari penelitian ini menunjukkan bahwa pelaksanaan penerimaan kas pada Rumah Sakit Umum Daerah Andi Makkasau telah dilakukan sesuai dengan Peraturan Daerah Nomor 2 (dua) tahun 2017 mencakup fungsi yang terkait meliputi fungsi pendaftaran pasien, administrasi keperawatan, pelayanan medis, penunjang medis, keuangan dan akuntansi serta dokumen yang digunakan. Sistem dan prosedur penerimaan kas sudah dilaksanakan dengan baik. Pelaksanaan sistem dan prosedur penerimaan kas dilakukan oleh beberapa fungsi pada rumah sakit.
\end{abstract}

\section{Pendahuluan}

Sebagai salah satu negara yang sedang berkembang, Indonesia saat ini sedang proses melaksanakan pembangunan di segala bidang. Pelaksanaan pembangunan ini bertujuan untuk meningkatkan pendapatan nasional sekaligus menjamin pemerataan pendapatan bagi seluruh rakyat Indonesia. Pembangunan sektor kesehatan perlu dipacu perkembangannya sehingga dapat membantu pemerintah sebagaimana yang diharapkan. Kebutuhan akan pelayanan kesehatan rumah sakit makin meningkat dan menuntut mutu pelayanan yang lebih tinggi. Sejalan dengan kemajuan yang dicapai di bidang ekonomi dan sosial budaya masyarakat, perlu dikembangkan rumah sakit yang baik dari dalam maupun dari luar rumah sakit. Oleh 
karena itu, diperlukan analisis siklus pendapatan, siklus pengeluaran, siklus konversi, siklus buku besar dan pelaporan agar tercapai usaha yang sehat dan rumah sakit yang semakin maju.

Rumah sakit menjadi unit pelayanan kesehatan yang populer di mata masyarakat sekarang ini. Seiring perkembangan zaman yang begitu modern dan serba cepat, banyak sekali makanan yang serba instan, gaya hidup pun juga instan, munculnya berbagai penyakit, dan kecelakaan ysng berdampak pada kesehatan. Oleh karena itu, rumah sakit berusaha meningkatkan pelayanan untuk memenuhi standar yang tinggi dan professional. Perkembangan masyarakat yang pesat menuntut setiap penyedia jasa memberikan layanan secara cepat, praktis, dan berkualitas.

Salah satu sistem yang diharapkan dapat menunjang keberhasilan adalah sistem penerimaan kas rumah sakit. Sistem penerimaan kas rumah sakit dirancang untuk mengetahui bagaimana proses atau cara penerimaan jumlah biaya yang dikenakan kepada pasien dari mulai pasien masuk rumah sakit sampai meninggalkan rumah sakit. Unsur-unsur sistem penerimaan kas di rumah sakit meliputi fungsi yang terkait, dokumen yang digunakan, dan jaringan prosedur yang membentuk sistem. Implementasi penerimaan kas harus memiliki sistem dan prosedur sesuai dengan peraturan yang ada.

Sistem dan prosedur akuntansi pada umumnya ditujukan untuk menyediakan informasi bagi pihak atau manajemen terkait perencanaan dan pengendalian dalam mengatasi kegiatan penyelewengan dan penyalahgunaan. Oleh karena itu, dalam sistem dan prosedur penerimaan khususnya penerimaan kas menyaratkan adanya pemisahan atas fungsi-fungsi secara jelas. Demikian pula pada Rumah Sakit Umum Daerah (RSUD) Andi Makkasau dalam menerima pendapatan yang akuntabel, transparan dan partisipasif sesuai dengan pandapatan yang diterima.

Rumah Sakit Umum Daerah (RSUD) Andi Makkasau merupakan salah satu instansi yang menangani jasa kesehatan bagi masyarakat. Menurut Peraturan Daerah Kota Parepare Nomor 2 Tahun 2017 tentang Tugas Pokok, Fungsi dan Rincian Tugas Rumah Sakit Umum Daerah Andi Makkasau, pendapatan Rumah Sakit Umum Daerah Andi Makkasau berasal dari berbagai pelayanan antara lain penerimaan yang berasal dari penjualan obat dan penerimaan dari rawat jalan. Motivasi instansi ini bukan pencapaian pada tingkat laba namun lebih mengutamakan pelayanan jasa kepada masyarakat. Walaupun demikian, bukan berarti bahwa tingkat keuntungan dari jasa yang diberikan tidak menjadi perhatian sama sekali. Pengawasan dan pengendalian terhadap penerimaan kas yang bersumber dari pelayanan terhadap pasien 
tetap mendapat perhatian dari manajemen.

Sistem penerimaan kas pokok dalam Rumah Sakit terdiri dari dua sumber yaitu penerimaan kas rawat jalan dan penerimaan kas rawat inap. Sistem informasi akuntansi penerimaan kas menjadi sangat diperhatikan karena kas merupakan kekayaan sebuah perusahaan yang sangat liquid. Penelitian ini menyoroti bagaimana prosedur penerimaan kas pada Rumah Sakit Umum Daerah Andi Makkasau yang berasal dari instalasi rawat inap. Hal ini karena sebagian besar sumber penerimaan Rumah Sakit Umum Daerah Andi Makkasau berasal dari instalasi rawat inap selain yang berasal dari pelayanan lain seperti rawat jalan, UGD (Unit Gawat Darurat), SKBS (Surat Keterangan Berbadan Sehat), SKBN (Surat Keterangan Bebas Narkoba) dan Rujukan Pasien. Penelitian ini menganalisis kelemahankelemahan yang perlu mendapat pembenaran oleh pihak manajemen dan kelebihan-kelebihan yang telah diterapkan oleh pihak manajemen.

\section{Metode Penelitian}

\subsection{Pendekatan Penelitian}

Penelitian menganalisis bagaimana prosedur penerimaan kas pada Rumah Sakit Umum Daerah Andi Makkasau yang berasal dari instalasi rawat inap dengan pendekatan kualitatif yang membandingkan antara konsep-konsep teori dan peraturan- peraturan dalam pelaksanaan sistem dan prosedur penerimaan kas, kemudian menarik kesimpulan. Lokasi Penelitian ini adalah Rumah Sakit Umum Daerah (RSUD) Andi Makkasau Kota Parepare dengan periode penelitian yaitu April-Agustus 2017. Data yang digunakan dalam penelitian ini adalah data kualitatif berupa dokumen, prosedur, dan informasi tentang pelaksanaan sistem dan prosedur. Pengumpulan data dilakukan dengan interview dan Teknik dokumentasi. Interview dilakukan dengan mengadakan serangkaian tanya jawab kepada pimpinan dan karyawan yang ada relevansinya dengan objek penulisan. Sementara dokumentasi dilakukan dengan mengambil/mengumpulkan data relevan sehubungan dengan penyiapan data yang diperlukan.

\subsection{Variabel Penelitian}

Variabel penelitian ini adalah system, prosedur, dan penerimaan kas. Sistem adalah suatu jaringan prosedur yang untuk melaksanakan kegiatan penerimaan kas di Rumah Sakit Umum Daerah (RSUD); prosedur adalah urutan klerikal melibatkan beberapa orang atau lebih, yang dibuat untuk menjamin penanganan transaksi penerimaan kas yang terjadi berulang-ulang; 
dan penerimaan kas adalah transaksi keuangan yang menyebabkan asset rumah sakit berupa kas atau setara kas bertambah.

\section{Hasil dan Pembahasan}

\subsection{Hasil}

Karakteristik bisnis BLUD (Badan Layanan Umum Daerah) RSUD Andi Makkasau merupakan unsur penyelenggaraan Pemerintah Kota Parepare di Bidang Pelayanan Kesehatan. Sifat bisnisnya adalah lembaga nonprofit/nirlaba yang lebih menekankan pada aspek pelayanan sosial kepada masyarakat utamanya masyarakat yang berada di bawah garis kemiskinan/kurang mampu sekaligus sebagai salah satu rumah sakit rujukan Propinsi Sulawesi Selatan (Pusat Rujukan Region Utara dan Sulawesi Barat). RSUD Andi Makkasau Kota Parepare sebagai Satuan Kerja Perangkat Daerah yang menerapkan Pola Pengelolaan Keuangan Badan Layanan Umum Daerah (PPK-BLUD) untuk meningkatkan fleksibilitas dan kuantitas pelayanan kesehatan kepada masyarakat berdasarkan prinsip efektif, efisien, dan produktif demi tercapainya Visi dan Misi RSUD A. Makkasau. Adapun tujuan yang ingin dicapai adalah:

a. Terwujudnya pelayanan kesehatan yang bermutu, terjangkau (biaya dan akses) dan manusiawi sebagai rumah sakit rujukan;

b. Terwujudnya rumah sakit dengan sumber daya yang profesional, akuntabel, dan berorientasi pada kepuasan pelanggan;

c. Terwujudnya sarana dan prasarana rumah sakit sesuai standar; dan

d. Terakomodirnya pelayanan kesehatan yang bermutu, terjangkau (biaya dan akses) dan manusiawi sebagai rumah sakit rujukan.

Adapun program kerja dan kegiatan RSUD A. Makkasau yaitu:

a. Program kerja: Program Peningkatan Pelayanan Kesehatan.

b. Kegiatan pelayanan terdiri: Pelayanan Rawat Jalan; Pelayanan Rawat Inap; Pelayanan Instalasi Gawat Darurat; Pelayanan Bedah Sentral; Pelayanan ICCU/ICU; Pelayanan Haemodialisa; Pelayanan NICU; Pelayanan VIP Room 1; Pelayanan VIP Room 2; Pelayanan Instalasi Laboratorium; Pelayanan Instalasi Radiologi; Pelayanan Instalasi Farmasi; Pelayanan Ambulance; Pelayanan Rehabilitasi Medik; Pelayanan Pendukung; Pelayanan penggunaan/Penyewaan Aset; Pelayanan Perizinan; dan Pelayanan Diklat. 


\section{Sistem Informasi Akuntansi}

Sistem informasi akuntansi adalah susunan berbagai dokumen, alat komunikasi tenaga pelaksana dan berbagai laporan yang didesain untuk mentransformasika data keuangan menjadi informasi keuangan (Widjajanto, 2001:4). Sistem informasi akuntansi terdiri dari beberapa elemen yaitu formulir, buku catatan, prosedur- prosedur serta laporan yang di desain untuk mentransformasikan data keuangan menjadi informasi keuangan. Pengembangan sistem informasi akuntansi mempunyai tujuan umum menyediakan informasi bagi pengelolaan kegiatan usaha baru; memperbaiki informasi yang dihasilkan oleh sistem yang sudah ada, baik mengenai mutu, ketetapan penyajian, maupun struktur informasinya; dan memperbaiki pengendalian akuntansi dan pengecekan internal; serta mengurangi biaya klerikal dalam penyelenggaraan catatan akuntansi.

\section{Sistem dan Prosedur Penerimaan Kas}

Fungsi yang terkait dalam sistem penerimaan kas meliputi fungsi penjualan, fungsi kas, dan fungsi akuntansi (Mulyadi, 2001). Dokumen yang digunakan dalam penerimaan kas meliputi faktur penjualan, pita register kas, dan bukti setor bank. Adapun catatan akuntansi yang digunakan meliputi jurnal penerimaan kas dan jurnal umum. Prosedur penerimaan kas meliputi prosedur penyetoran kas ke bank dan prosedur pencatatan penerimaan kas. Fungsi yang terkait dalam prosedur ini adalah:

a. Fungsi Pendaftaran Pasien

Fungsi ini bertanggung jawab mendaftar pasien yang akan rawat inap. Kemudian memilih ruangan serta diberi nomor register masuk. Fungsi ini dilakukan oleh petugas pendaftaran di IGD.

b. Fungsi Administrasi Keperawatan

Fungsi ini bertanggung jawab untuk mengecek kebenaran identitas pasien tinggal, ruangan yang ditempati pasien serta penanggungjawab pasien tinggal. Fungsi ini dilakukan oleh perawat.

c. Fungsi Pelayanan Medis

Fungsi ini bertugas untuk memberikan pelayanan medis kepada pasien rawat inap serta melakukan pancatatan baik medis, obat- obatan yang diperlukan pasien serta barang habis pakai. 


\section{d. Fungsi Penunjang Medis}

Bertugas memberikan pelayanan kepada pasien untuk dirujuk ke unit-unit penunjang seperti radiologi, fisioterapi, dan laboratorium.

e. Fungsi Keuangan

Fungsi ini bertugas untuk menerima semua kas yang masuk baik yang diterima dari Instalasi rawat inap, rawat jalan serta jasa pelayanan lainnya. Fungsi ini dilakukan oleh bagian Bendahara Penerimaan.

\section{f. Fungsi Akuntansi}

Tugas dari fungsi ini untuk menghitung dan mencatat seluruh transaksi penerimaan kas ke jurnal penerimaan kas untuk kemudian membuat laporan kas masuk harian. Fungsi ini dilaksanakan oleh bagian akuntansi.

\section{Dokumen yang Digunakan}

Dokumen yang digunakan dalam penerimaan kas rawat inap Rumah Sakit Umum Daerah Andi Makkasau Kota Parepare adalah:

a. Surat Konsul (SK) Kartu Status Pasien

Berisi tentang diagnosa dokter serta obat-obatan yang diberikan kepada pasien sebagai refrensi riwayat penyakit pasien.

b. Kartu Penderita Mondok (KPM)

Kartu rekam medis kartu yang berisi nomor register masuk pasien serta identitas pasien kemudian diserahkan ke pasien.

c. Daftar Penderita Mondok (DPM)

Daftar yang berisi berdasarkan data yang diperoleh dari surat konsult, daftar ini berisi nama pasien diagnosa penyakit yang dibuat rangkap 2 (dua).

d. Nota Bangsal (NB)

Berisi biaya dari transaksi yang dilakukan pasien, nota ini dibuat setiap hari oleh perawat pada masing-masing bangsal, nota bangsal dibuat rangkap 3 (tiga).

e. Nota Farmasi (NF)

Nota yang berisi semua biaya obat-obatan habis pakai yang digunakan di bangsal.

f. Perintah Dokter (PDr)

Berisi tindakan medis yang harus dilakukan dalam menangani pasien masuk sesuai dengan perintah dokter. 


\section{g. Catatan Perawat}

Catatan perawat berisi perawatan yang diberikan kepada pasien selama rawat inap.

h. Tanda Terima Uang Muka (TTUM)

Berisi jumlah pembayaran uang muka yang dibayarkan pasien, tanda terima uang muka ini dibuat rangkap 3 (tiga).

i. Tanda Pulang (TP)

Tanda pulang merupakan catatan yang menandakan bahwa pasien sudah diizinkan pulang dan telah dinyatakan sembuh. Tanda pulang lembar pertama diserahkan kembali ke perawat setelah pasien menyelesaikan pembayaran ke kasir.

\section{Catatan Akuntansi yang Digunakan}

a. Buku Mondok (BM)

Buku yang berisi daftar pasien rawat inap sesuai dengan data pada KPM dan DPM. Pencatatan pada buku mondok ini dilakukan oleh perawat.

b. Buku Register (BK)

Buku yang berisi nama pasien, nomor register masuk, ruangan pasien. Buku ini digunakan untuk mencatat rincian biaya yang telah dibayarkan pasien.

c. Jurnal Penerimaan Kas

Jurnal yang berfungsi untuk mencatat semua transaksi penerimaan kas, baik yang diperoleh dari instalasi rawat inap maupun rawat jalan serta penerimaan kas lainnya.

d. Laporan Akhir Bulan

Laporan yang berisi jumlah kas yang diterima dalam satu bulan. Laporan kas ini dibuat pada akhir bulan.

e. Laporan Kas Harian (LKH)

Laporan yang berisi jumlah kas yang diterima. Laporan ini dibuat per tanggal pada instalasi rawat inap.

f. Buku Besar

Laporan yang dibuat untuk menggolongkan penerimaan kas berdasarkan pos-posnya.

\section{Jaringan Prosedur yang Membentuk Sistem}

a. Prosedur penerimaan pasien masukdilakukan oleh bagian pelaksana pendaftaran, bagian administrasi keperawatan dan bagian billing.

b. Bagian pelaksana pendaftaran, menerima surat konsul dari pasien. 
c. Berdasarkan surat konsult (SK), dibuat daftar penderita Mondok (DPM) rangkap 2 (dua) dan di catat ke kartu penderita mondok (KPM) dan buku register (BR).

d. Setelah administrasi selesai, pasien dibawa ke perawat pada seksi perawatan.

e. Perawat menerima KPM dan DP lembar pertama dari petugas pendaftaran kemudian bagian billing menerima DPM lembar kedua dari petugas pendaftaran.

f. Pendaftaran DPM, petugas billing memasukkan data pasien ke komputer.

\section{Prosedur Perawatan Pasien}

Pelaksanaan prosedur perawatan pasien dilakukan oleh bagian administrasi keperawatan, bagian billing dan bagian staf catatan medis adalah sebagai berikut:

a. Berdasarkan kartu penderita mondok (KPM) dan daftar penderita mondok (DPM), perawat melakukan pencatatan ke buku mondok (BM) dan buku pemakaian kamar (BPK), kemudian diadakan konsul dokter.

b. Sesuai dengan konsul dokter, dibuat perintah dokter (PDr) rangkap 1, perawatan penderita dicatat dalam catatan perawat (CPwt) rangkap 1, perawat setiap hari membuat nota rangkap 3 (tiga). Nota lembar 1 dan 2 diberikan ke bagian billing, lembar 3 untuk arsip.

c. Pada saat pasien diizinkan pulang, dibuat tanda pulang (TP) rangkap 1, KPM, DPM lembar pertama, PDr lembar 1 dan CPwt lembar 1 diserahkan ke staf catatan medis.

d. Bagian billing menerima Nota lembar 1, 2 dari seksi perawatan untuk di input ke komputer.

e. Bagian catatan medis menerima KPM, DPM lembar 1, PDr lembar 1, CPwt lembar 1 dari seksi perawat untuk arsip.

\section{Prosedur Penginputan Penagihan}

Prosedur penginputan penagihan dilakukan oleh bagian billing dan bagian kasir. Bagian billing melakukan verifikasi terhadap nota perawatan pasien rawat inap dari tiap unit yang dicatat secara manual untuk dilakukan penginputan ke komputer. Setelah proses penginputan selesai, billing dicetak dengan rincian biaya rawat inap (RBRI). Berdasarkan rincian biaya rawat inap yang dicetak billing, bagian kasir membuat kuitansi perawatan (KP).

\section{Prosedur Penerimaan Pembayaran dari Pasien Pulang}

Prosedur penginputan penagihan dilakukan oleh bagian billing. Bagian keperawatan dan bagian kasir. Kasir membuat kuitansi perawatan (KP) lembar pertama dan kedua, tanda 
terima uang muka (TTUM) lembar ketiga dan nota berdasarkan penginputan yang dilakukan oleh billing. Kasir bagian keuangan menerima uang dari pasien, kemudian uang dari pasien dicocokkan dengan bukti-bukti dokumen pasien dan membuat laporan penerimaan kas/bank inpatient (LPKBI) rangkap 2 (dua). Setelah semua proses selesai, KPN lembar 1 dan nota lembar 1 diberikan kepada pasien kemudian uang KPN lembar 2 dan TTUM lembar 3 dan LPKBI lembar 1 dan lembar 2 diarsipkan. Perawat menerima tanda pulang (TP) lembar pertama dari pasien kemudian pasien diperbolehkan pulang. Prosedur pencatatan dan penyetoran pembayaran dari pasien pulang dilakukan oleh bagian billing meliputi kepala seksi keuangan, kepala bagian keuangan, dan bagian akuntansi.

\subsection{Pembahasan}

\section{Fungsi yang Terkait}

Pelaksanaan sistem penerimaan kas yang telah dijalankan pada RSUD Andi Makkasau Kota Parepare sudah melakukan pemisahan fungsi yang baik antar fungsi operasi, fungsi pencacatan, dan fungsi penyimpanan. Fungsi operasi dilaksanakan oleh bagian pendaftaran pasien, bagian administrasi keperawatan, bagian pelayanan medis, dan bagian penunjang medis. Bagian pendaftaran bertugas melakukan pendaftaran pasien masuk. Bagian administrasi keperawatan berfungsi mengecek kebenaran identitas pasien tinggal, ruangan yang ditempati pasien serta penanggungjawab pasien bagian pelayanan medis bertugas memberikan pelayanan pasien rawat inap. Bagian penunjang medis bertugas memberikan pelayanan untuk dirujuk ke unit-unit penunjang. Fungsi pendaftaran dilakukan oleh bagian akuntansi. Bagian akuntansi bertugas melakukan pencacatan serta perhitungan seluruh transaksi penerimaan kas untuk kemudian dibuat laporan kas masuk harian. Fungsi penyimpanan dilaksanakan oleh bagian keuangan. Bagian keuangan berfungsi menerima semua kas masuk yang diterima dari instalasi rawat inap maupun jasa pelayanan lainnya.

\section{Dokumen yang Digunakan}

Dokumen-dokumen yang terdapat pada RSUD Andi Makkasau sudah baik. Hal ini dibuktikan dengan adanya otorisasi oleh pihak yang berwenang. Setiap dokumen terdiri dari 2 (dua) rangkap yang masing-masing bagian kasir, pasien dan untuk arsip. Akan tetapi, dalam penanganannya masih terdapat kelemahan. Kelemahan ini disebabkan oleh keteledoran petugas billing dalam meletakkan print out kartu debitur. Hasil print out kartu debitur yang seharusnya diletakkan pada box atau lemari tersendiri justru diletakkan pada box yang 
bercampur dengan tumpukan dokumen lainnya. Hal ini menyebabkan terselipnya kartu debitur sehingga terjadi keterlambatan pengiriman kartu debitur ke bagian akuntansi untuk dilakukan pencacatan.

Mengingat kartu debitur merupakan dokumen yang paling penting dalam transaksi rawat inap. Hal ini sangat mengangu dalam pembuatan laporan kas harian. Banyaknya kuitansikuitansi yang perlu dicatat mengakibatkan kurang telitinya para staf dalam melakukan pencacatan sehingga seringkali terjadi kesalahan dalam memasukkan identitas pasien dan tidak balance antara uang yang diterima dengan laporan kas harian yang dicatat dan dihitung bagian akuntansi.

\section{Jaringan Prosedur yang Membentuk Sistem}

Jaringan prosedur yang membentuk sistem penerimaan kas pada RSUD Andi Makkasau sudah terorganisir dengan baik antara prosedur penerimaan kas, prosedur penyetoran kas ke bank, dan prosedur pencatatan kas. Rangkaian prosedur RSUD Andi Makkasau dimulai dari prosedur rawat inap, prosedur perawatan pasien, prosedur penginputan penagihan, prosedur penerimaan pembayaran dari pasien pulang, prosedur penyetoran, dan pencatatan pembayaran pasien pulang. RSUD Andi Makkasau tidak menerapkan prosedur penyetoran kas ke bank karena semua biaya yang harus dibayar pasien langsung dibayarkan pada bank yang terdapat pada RSUD Andi Makkasau. Hal ini dapat digunakan untuk mengurangi kemungkinan hilangnya sejumlah uang karena begitu banyaknya jumlah biaya pasien rawat inap yang pulang pada tanggal yang sama. Kesalahan yang sering ditimbulkan biasanya berasal dari karyawan/staf yang mengalami kejenuhan dalam bekerja. Hal ini dipicu dengan pekerjaan yang monoton dengan jumlah pekerjaan terlalu banyak. Sehingga menyebabkan staf kurang teliti dalam melakukan pekerjaan.

Berdasarkan Uraian diatas maka penulis dapat menjabarkan secara spesifikasi bagaimana komponen-komponen penting dalam Penerimaan Kas sebagai berikut:

a. Sistem dan Prosedur Akuntansi

Pelaksanaan sistem dan prosedur penerimaan kas yang dilakukan pada Rumah Sakit Umum Daerah Andi Makkasau Kota Parepae mulai dari pencatatan, penggolongan, dan transaksi keuangan secara manual ataupun komputerisasi sudah dilakukan dengan baik. Terkait pencatatan dan penggolongan, STS yang telah di otorisasi oleh bank dikembalikan kepada Bendahara Penerimaan untuk kemudian menjadi bukti pembukuan yang dicatat. 
Pasien menyerahkan/menyetor uang kepada bendahara penerimaan kemudian bendahara penerimaan melakukan verifikasi penerimaan uang dan mengeluarkan surat tanda bukti pembayaran. Selanjutnya melakukan penyetoran ke bank disertai STS. Setelah itu dikembalikan ke bendahara penerimaan untuk bukti pembukuan.

b. Otorisasi

Proses Pengendalian aktivitas penerimaan kas setiap dokumen dasar penerimaan kas diharuskan diotorisasi dahulu oleh pejabat yang bersangkutan. Setiap pejabat yang melakukan otorisasi memiliki tanggungjawab dari penggunaan bukti itu. Setiap bukti dasar penerimaan kas diotorisasi oleh pejabat berwenang. Proses pengotorisasi dimulai dengan pengesahan-pengesahan dokumen dasar. Penerimaan kas pada rawat inap dimulai dengan pengesahan bukti setoran sebelum penerimaan tersebut disetor ke bank melalui STS.

c. Formulir, Dokumen, dan Catatan Akuntansi

Pelaksanaan penerimaan kas terhadap formulir, dokumen dan catatan penerimaan kas pada Rumah Sakit Umum Daerah Andi Makkasau hampir dilaksanakan dengan baik. Dokumen dan catatan yang digunakan dalam proses penerimaan kas ada beberapa yang belum menyesuaikan dengan bentuk dokumen dan catatan yang ada.

d. Pemisahan Tugas

Pemisahan tugas dalam proses pelaksanaan penerimaan kas pada Rumah Sakit Umum Daerah Andi Makkasau telah dilaksanakan dengan baik. Fungsi terkait tidak ada yang merangkap dua fungsi sekaligus. Penerimaan kas rumah sakit umum daerah dilakukan oleh beberapa fungsi. Semuanya dipisahkan secara independen sesuai dengan tugas yang akan dikerjakan.

\section{Evaluasi Pelaksanaan Sistem dan Prosedur Penerimaan Kas}

Berkaitan dengan Perda Nomor 2 tahun 2017 tentang Pelaksanaan Pembukuan Penerimaan Kas Pendapatan dari Pasien Rawat Inap dalam pelaksanaan Prosedur ini telah dilakukan dengan baik. Hal ini terlihat secara keseluruhan prosedur Penerimaan kas diotorisasi oleh pejabat yang berwenang. Sedangkan bentuk dokumen-dokumen yang digunakan telah sesuai dengan bentuk-bentuk dokumen yang sesuai antara lain Surat Konsult Pasien (SK) Kartu Status Pasien, Kartu Penderita Mondok (KPM) Kartu Rekam Medik, Daftar Penderita Mondok (DPM), Nota Bangsal (NB), Nota Farmasi (NF), Perintah Dokter 
(PDr), catatan Perawat, tanda terima uang muka (TTUM), Tanda Pulang (TP).

Setiap akhir bulan sebelum melakukan tutup buku dilakukan pencocokan antara buku besar penerimaan dengan buku kas umu untuk meminimalisir kesalahan terhadap pelaksanaan pencatatan yang digunakan oleh petugas pencatat bagian pembukuan/akuntansi. Hal ini karena dari hasil penelitian yang diperoleh memperlihatkan bahwa terjadinya kesalahankesalahan baik salah catat atau tidak dicatatnya suatu rekening sering kali terjadi. Berdasarkan uraian tersebut, diketahui bahwa sistem dan prosedur penerimaan kas yang dilaksanakan oleh Rumah Sakit Umum Daerah Andi Makkasau Kota Parepare sudah sesuai dengan sistem dan prosedur yang tertuang dalam Perda Nomor 2 tahun 2017 untuk pelaksanaan pembukuan penerimaan pendapatan dari pasien rawat inap.

\section{Kesimpulan dan Saran}

Pelaksanaan penerimaan kas pada Rumah Sakit Umum Daerah Andi Makkasau telah dilakukan sesuai dengan Peraturan Daerah Nomor 2 Tahun 2017 yang mencakup fungsi yang terkait antara lain fungsi pendaftaranpasien, fungsi administrasi keperawatan, fungsi pelayanan medis, fungsi penunjang medis, fungsi keuangan, dan fungsi akuntansi serta dokumen yang digunakan.

Sistem dan prosedur sistem penerimaan kas sudah dilaksanakan dengan baik. Pelaksanaan sistem dan prosedur penerimaan kas Surat Tanda Setor (STS) merupakan dokumen dasar yang digunakan pada pencatat penerimaan kas. Pelaksanaan sistem dan prosedur penerimaan kas dilakukan oleh beberapa fungsi yaitu, pada rumah sakit selaku fungsi yang menyetor penerimaan kas, Bank selaku lembaga keuangan yang dipakai Pemerintah Kota Parepare dalam hal menyimpan uang daerah. Bendahara Penerimaan sebagai fungsi yang mengesahkan bahwa benar ada terjadi penerimaan kas di rekening kas daerah. Bidang pembukuan/akuntansi selaku fungsi pencatatan.

Diharapkan kepada pihak Rumah Sakit Umum Daerah khususnya bagian penerimaan kas agar kiranya sebelum melakukan tutup buku dilakukan pencocokan antara buku besar penerimaan dengan buku kas umum, karena dari hasil penelitian yang diperoleh memperlihatkan bahwa terjadinya kesalahan-kesalahan baik salah catat atau tidak dicatatnya suatu rekening sering kali terjadi. Selain itu perlu lebih meningkatkan sistem dan prosedur penerimaan kas. 


\section{Daftar Pustaka}

Bastian, I. 2007. Sistem Akuntasi Sektor Publik. Jakarta: Salemba Empat.

Cahyani, A.F. 2014. Sistem Pengendalian Internal Kas di Koperasi Serba Usaha (KSU) Baitul Maal Wa Tamwil (BMT) Sejahtera Sleman. Jurnal Fakultas Dakwah dan Komunikasi: $50-56$.

Halim, A. 2008. Akuntansi Keuangan daerah. Jakarta: Salemba Empat.

Halim, Restianto, dan Karman. 2010. Sistem Akuntansi Sektor Publik. Yogyakarta: UPP STIM YKPM.

Hartina, S. 2009. Analisis Penyajian Laporan Keuangan Derah pada Pemerintahan Kabupaten Langkat., Jurnal Niaga dan Bisnis, 1: 9-14.

Jaluanto. Rekayasa Siklus Penerimaan Kas Studi Kasus pada Rumah Sakit Swasta di Semarang. Jurnal Ekonomi Untag Semarang: 4-10.

Karamoy, R.C. 2014. Evaluasi Pelaksanaan sistem dan prosedur penerimaan kas di Dinas Pendapatan kota Manado. Jurnal Riset Akuntansi, 12-17.

Kuncoro, M. 2009. Metode Riset untuk Bisnis dan Ekonomi. Jakarta: Erlangga.

Mahmudi. 2005. Manajemen Kinerja Sektor Publik. Edisi Pertama. Yogyakarta: UPP AMP YKPN.

Marshall, R. dan P. J. Steinbart. 2006. Accounting Information Systems. Edisi Kesembilan. Jakarta: Salemba Empat.

Mulyadi. 2001. Sistem Akuntansi. Edisi Ketiga. Jakarta: Salemba Empat.

Nugroho, W. 2001. Sistem Akuntansi. Edisi Kedua. Jakarta: Salemba Empat.

Prihanto. 2010. Evaluasi Sistem Informasi Akuntansi Penerimaan Kas dari Instalasi Rawat Inap pada RSUD Karanganyar. Jurnal Manajemen dan Kewirausahaan, 8-11.

Republik Indonesia. Peraturan Dalam Negeri No. 13 Tahun 2006 Tentang Pedoman Pengelolaan Keuangan Daerah Yang Mengatur Mengenai Pedoman Pengurusan, Pertanggung Jawaban Dan Pengawasan Keuangan Daerah.

Republik Indonesia. Peraturan Menteri dalam Negeri Nomor 59 Tahun 2007 tentang Pedoman Pengelolaan Keuangan Daerah.

Republik Indonesia. Peraturan Menteri dalam Negeri Nomor 71 Tahun 2010 tentang Standar Akuntansi Pemerintah.

Republik Indonesia. Undang- Undang Nomor 25 Tahun 2009 tentang Pelayanan Publik. 
Republik Indonesia. Undang-Undang Nomor 01 Tahun 2004 tentang Perbendaharaan Negara.

Republik Indonesia. Undang-Undang Nomor 147 Tahun 2010 tentang Perizinan Rumah Sakit.

Republik Indonesia. Undang-Undang Nomor 15 Tahun 2005 tentang Pemeriksaan Keuangan Negara.

Republik Indonesia. Undang-Undang Nomor 17 Tahun 2003 tentang Keuangan Negara.

Republik Indonesia. Undang-Undang Nomor 36 Tahun 2009 tentang Kesehatan.

Widjajanto. 2008. Sistem Informasi Akuntansi. Lampung: Sekolah Tinggi Ilmu Ekonomi Lampung. 